\title{
Synthesis, Crystal Structure, Vibrational Study and DFT Computation of Barium Dihydrogenomonophosphate $\mathrm{Ba}\left(\mathrm{H}_{2} \mathrm{PO}_{4}\right)_{2}$
}

\author{
Rachida Oubouaza $^{1(\mathbb{D})}$, Mark Benson ${ }^{2(\mathbb{D})}$, Jakub Wojciechowski ${ }^{3(\mathbb{D})}$, Samir Chtita ${ }^{4}$, \\ Malika Tridane $^{5}$ (i) , Said Belaaouad ${ }^{6}$ (i)
}

1 Laboratory of chemistry-physics of materials LCPM, Faculty of Sciences Ben M'Sik, B.P7955, Hassan II University of Casablanca, Morocco; oubouazarachida01@ gmail.com (R.O.);

2 Institute of General and Ecological Chemistry, Łód'z University of Technology, 116 Zeromskiego St., 90-924 Lodz, Poland; mark.benson@ rigaku.com (M.B.);

3 Department of Chemistry, University of Liverpool, Crown Street, Liverpool L697ZD, UK; wojciechowski@ rigaku.com (J.W.);

4 Laboratory of Chemistry-Physics of Materials LCPM, Faculty of Sciences Ben M'Sik, B.P7955, Hassan II University of Casablanca, Morocco; samirchtita@gmail.com (S.C.);

5 Regional Center of the Education and Training Trades Anfa Bd BirAnzarane Casablanca, Morocco; tridane.malika@gmail.com (M.T.);

6 Laboratory of Chemistry-Physics of Materials LCPM, Faculty of Sciences Ben M'Sik, B.P7955, Hassan II University of Casablanca, Morocco; sbelaaouad@yahoo.fr (S.B.);

* Correspondence: oubouazarachida01@gmail.com;

Scopus Author ID 57218932956

Received: 3.03.2021; Revised: 6.04.2021; Accepted: 9.04.2021; Published: 26.04.2021

\begin{abstract}
The single crystal of barium dihydrogenomonophosphate, $\mathrm{Ba}\left(\mathrm{H}_{2} \mathrm{PO}_{4}\right)_{2}$ was prepared by the direct method. This compound exists in two forms: one orthorhombic, the other triclinic. In this work, we are interested in the triclinic form from the vibrational and crystalline side too. X-ray crystallography showed that this compound crystallizes in the triclinic centrosymmetric with space group P-1 ( $\mathrm{Z}=2)$ with $\mathrm{a}=6.9917(5) \AA, \mathrm{b}=7.1929(5) \AA, \mathrm{c}=7.9667(9) \AA, \alpha=104.517(8)^{\circ}, \beta=95.918(7)^{\circ}$ and $\gamma=109.459(6)$. The structure was solved from 3444 independent reflections with $R=0.0198$ with $w R=0.0633$. The bands observed in the infrared and Raman spectra of $\mathrm{Ba}\left(\mathrm{H}_{2} \mathrm{PO}_{4}\right)_{2}$ are assigned based on the literature results and the theoretical group analyses carried out in the group of factors $\mathrm{Ci}$. The optimal molecular geometry, harmonic vibrational frequencies, infrared intensities, and Raman scattering activities were calculated using density functional theory (DFT/B3LYP) methods with the LanL2DZ basis set. The HOMO-LUMO properties and geometries of this compound have been determined and discussed. The computational structural parameters are generally in agreement with the experimental investigations. The theoretical infrared and Raman spectra for the title compound have been constructed.
\end{abstract}

Keywords: crystal structures; X-ray diffraction; Raman; Infrared; DFT; barium dihydrogenomonophosphate.

(C) 2021 by the authors. This article is an open-access article distributed under the terms and conditions of the Creative Commons Attribution (CC BY) license (https://creativecommons.org/licenses/by/4.0/).

\section{Introduction}

The title compound belongs to a family of Dihydrogenophosphate with the general formula $\mathrm{MH}_{2} \mathrm{PO}_{4}\left(\mathrm{M}=\mathrm{K}, \mathrm{Rb}, \mathrm{Cs}, \mathrm{NH}_{4}, \mathrm{Tl}\right)$. The sample presents some physical and chimical propreties of intersting materials for potential applications, such as chemical sensors, ionic conductors, catalysts, and adsorbents [1-8]. This compound has been synthesized and studied 
by single-crystal X-ray diffraction analysis, infrared and Raman vibrational. This compound crystallizes in the triclinic system with the space group P-1.

The compound, $\mathrm{Ba}\left(\mathrm{H}_{2} \mathrm{PO}_{4}\right)_{2}$, is isostructural with $\mathrm{Sr}\left(\mathrm{H}_{2} \mathrm{PO}_{4}\right)_{2}$ [1]. The single crystal dihydrogenomonophosphate of barium. This compound exists in two forms: one orthorhombic [2], the other triclinic. In this work, we are interested in the triclinic form from the vibrational and crystalline sides too. The present paper reports the synthesis, the crystal structure determination of the title compound by X-ray diffraction at room temperature, and the experimental and computational vibrational studies of a phosphate, which is characterized by the existence of $\mathrm{Ba}^{2+}$ and $\mathrm{H}_{2} \mathrm{PO}_{4}^{-}$. The three-dimensional structure can be considered as consisting of independent $\left[\mathrm{PO}_{4}\right]$ tetrahedra. Two vertices of each tetrahedron $\left[\mathrm{PO}_{4}\right]^{3-}$ are connected to two $\mathrm{H}$ atoms to form phosphate $\left[\mathrm{H}_{2} \mathrm{PO}_{4}\right]^{-}$anions arranged to delimit large deformed cavities occupied by barium-cations. The Hydrogen atoms were positioned in idealized positions and included in the final cycles of refinement. We have obtained the best structural refinement with a final value of $\mathrm{R}=0.0198$ with $\mathrm{w} R=0.0633$.

\section{Materials and Methods}

\subsection{Materials.}

Orthophosphoric acid $\mathrm{H}_{3} \mathrm{PO}_{4}(85 \%)$ and strontium carbonate, $\mathrm{BaCO}_{3}(98 \%)$, supplied by Merck, were used to prepare the single crystal of Barium dihydrogenomonophosphate, $\mathrm{Ba}\left(\mathrm{H}_{2} \mathrm{PO}_{4}\right)_{2}$.

\subsection{Crystal growth.}

Single crystals of barium dihydrogen phosphate $\mathrm{Ba}\left(\mathrm{H}_{2} \mathrm{PO}_{4}\right)_{2}$, was prepared by slowly adding $0.98 \mathrm{~g}(10 \mathrm{mmol})$ dilute $\mathrm{H}_{3} \mathrm{PO}_{4}(85 \%)$, neutralized with stoichiometric amounts of 0.20 g (2 mmol) Barium carbonate, $\mathrm{BaCO}_{3}(98 \%)$. The so-obtained solution was then slowly evaporated at room temperature. Clear and good quality single crystals of parallelepiped shape were then recovered for an X-ray diffraction study.

\subsection{X-ray diffraction and data collection.}

XRD analyses were performed on $\mathrm{Ba}\left(\mathrm{H}_{2} \mathrm{PO}_{4}\right)_{2}$ using a single-crystal X-ray diffractometer (RigakuXtaLAB Synergy-S) operating in Debye Scherrer geometry using Cu$\mathrm{K} \alpha$ radiation and equipped with a HyPix $-6000 \mathrm{HE}$ area detector [9].

\subsection{Infrared spectroscopy.}

The infrared spectrum was recorded from $400-4000 \mathrm{~cm}^{-1}$ with a Bruker tensor-27 FTIR spectrometer, using samples dispersed in spectroscopically pure $\mathrm{KBr}$ pellets (about $1 \%$ by mass of compound).

\subsection{Raman spectroscopy.}

The Raman spectrum was recorded from $100-3500 \mathrm{~cm}^{-1}$ with a Raman dispersive microscope DXR2 (Thermo scientific). Excitation was accomplished with the $633 \mathrm{~nm}$ line of an argon-ion laser. Incident power was approximately $6 \mathrm{Mw}$ at the source and $10 \%$ of that at the sample. 


\section{Results and Discussion}

\subsection{Structure of $\mathrm{Ba}\left(\mathrm{H}_{2} \mathrm{PO}_{4}\right)_{2}$ crystal.}

$\mathrm{X}$-ray diffraction of the $\mathrm{Ba}\left(\mathrm{H}_{2} \mathrm{PO}_{4}\right)_{2}$ crystal showed that this compound crystallized in the triclinic system with $\mathrm{P}-1$.The crystallographic data collection and the structure refinement are presented in Table 1.

The hydrogen atoms were placed in idealized positions and included in the final refinement cycles; we also got the best structural refinement, we found the final value of $\mathrm{R}, \mathrm{R}=$ $0.0198, w R=0.0633$. Refined atomic positions and isotropic thermal factors are given in Table 2. The anisotropic thermal factors are given in Table 3. The interatomic distances $(\AA)$ and angles are presented in Table 4.

Table 1. Crystal structure data for $\mathrm{Ba}\left(\mathrm{H}_{2} \mathrm{PO}_{4}\right)_{2}$.

\begin{tabular}{|c|c|}
\hline Formula & $\mathrm{Ba}\left(\mathrm{H}_{2} \mathrm{PO}_{4}\right)_{2}$ \\
\hline $\begin{array}{l}\text { Formula weight } \\
(\mathrm{g} / \mathrm{mol})\end{array}$ & 331.31 \\
\hline Temperature (k) & $100(10)$ \\
\hline Wavelength $(\AA)$ & 0.71073 \\
\hline Crystal system & Triclinic \\
\hline Space group & $\mathrm{P}-1$ \\
\hline $\mathrm{a}(\AA)$ & $6.9917(5)$ \\
\hline $\mathrm{b}(\AA)$ & $7.1929(5)$ \\
\hline c $(\AA)$ & $7.9667(9)$ \\
\hline$\alpha\left(^{\circ}\right)$ & $104.517(8)$ \\
\hline$\beta\left(^{\circ}\right)$ & $95.918(7)$ \\
\hline$\gamma\left({ }^{\circ}\right)$ & $109.459(6)$ \\
\hline Volume $\left(\AA^{3}\right)$ & $357.98(6)$ \\
\hline $\mathrm{Z}$ & 2 \\
\hline $\begin{array}{l}\text { Calculated density } \\
(\mathrm{g} / \mathrm{cm} 3)\end{array}$ & 3.074 \\
\hline Crystal size $(\mathrm{mm})$ & $\begin{array}{l}0.076 \times 0.087 \times \\
0.125\end{array}$ \\
\hline Color & Colorless \\
\hline Diffractometer & $\begin{array}{l}\text { RigakuXtaLAB } \\
\text { Synergy-S }\end{array}$ \\
\hline $\mathrm{F}(000)$ & 308 \\
\hline $\begin{array}{l}\text { Absorption } \\
\text { coefficient }(\mathrm{mm}-1)\end{array}$ & 5.996 \\
\hline $2 \theta$ Range $\left({ }^{\circ}\right)$ & $5-61$ \\
\hline Index ranges & $\begin{array}{l}-9 \leq \mathrm{h} \leq 9,-10 \leq \mathrm{k} \\
\leq 10,-11 \leq 1 \leq 11\end{array}$ \\
\hline $\begin{array}{l}\text { Reflections collected } \\
I>2 \sigma(I)\end{array}$ & 3444 \\
\hline Unique data $\mathrm{I}>2 \sigma(\mathrm{I})$ & 3444 [Rint= 2.26] \\
\hline $\begin{array}{l}\text { Data/restraints/param } \\
\text { eters }\end{array}$ & $3444 / 3 / 116$ \\
\hline Goodness of fit on F2 & 1.098 \\
\hline $\begin{array}{l}\text { Final R factors ( I > } \\
2 \sigma(\mathrm{I}))\end{array}$ & $\begin{array}{l}\mathrm{R} 1=0.0198, \mathrm{wR} 2= \\
0.0633\end{array}$ \\
\hline $\begin{array}{l}\text { Final R factors (all } \\
\text { data) }\end{array}$ & $\begin{array}{l}\mathrm{R} 1=0.0199, \mathrm{wR} 2= \\
0.0634\end{array}$ \\
\hline Extinction coefficient & $0.024(2)$ \\
\hline $\begin{array}{l}\text { Largest residual peak } \\
\text { / hole }(\mathrm{e} \AA-3)\end{array}$ & 0.826 and -0.701 \\
\hline
\end{tabular}


Table 2. Atomic positions and thermal isotropic factorsfor $\mathrm{Ba}\left(\mathrm{H}_{2} \mathrm{PO}_{4}\right)_{2}$ in the space group $\mathrm{P}-1$.

\begin{tabular}{l|l|l|l|l} 
Atom & $\mathbf{X}$ & $\mathbf{Y}$ & $\mathbf{Z}$ & Uiso*/Ueq \\
\hline Ba01 & $0.76557(2)$ & $0.79495(2)$ & $0.59237(2)$ & $0.00457(8)$ \\
\hline P002 & $0.74095(10)$ & $1.22505(11)$ & $0.40438(9)$ & $0.00536(14)$ \\
\hline P003 & $0.78872(11)$ & $0.69863(12)$ & $0.07735(10)$ & $0.00679(14)$ \\
\hline O004 & $0.8888(3)$ & $1.2984(4)$ & $0.2786(3)$ & $0.0100(4)$ \\
\hline O005 & $0.9685(3)$ & $0.9041(4)$ & $0.1103(3)$ & $0.0098(4)$ \\
\hline O006 & $0.6487(3)$ & $0.7079(3)$ & $0.2093(3)$ & $0.0070(4)$ \\
\hline O007 & $0.6669(3)$ & $0.6521(3)$ & $-0.1152(3)$ & $0.0082(4)$ \\
\hline O008 & $0.5395(3)$ & $1.0369(3)$ & $0.2874(3)$ & $0.0099(4)$ \\
\hline O009 & $0.8648(3)$ & $1.1529(3)$ & $0.5193(3)$ & $0.0072(4)$ \\
\hline O00A & $0.8625(4)$ & $0.5214(4)$ & $0.0770(3)$ & $0.0103(4)$ \\
\hline H00A & $0.6580(3)$ & $1.3855(3)$ & $0.4858(3)$ & $0.0086(4)$ \\
\hline H005 & 1.000000 & 0.500000 & 0.000000 & $0.16(8)$ \\
\hline H007 & 1.000000 & 1.000000 & 1.000000 & $0.15(7)$ \\
\hline H004 & $0.587(7)$ & $0.550(6)$ & $-0.149(8)$ & $0.025(14)$ \\
\hline H008 & $0.856(7)$ & $1.357(7)$ & $0.225(6)$ & $0.010(11)$ \\
\hline
\end{tabular}

Table 3. Thermal anisotropic factors $\left(\AA^{2} 10^{5}\right)$ refined in the space group $\mathrm{P}-1$ for $\mathrm{Ba}\left(\mathrm{H}_{2} \mathrm{PO}_{4}\right)_{2}$.

\begin{tabular}{l|l|l|l|l|l|l} 
Atom & $\mathbf{U 1 1}$ & $\mathbf{U 2 2}$ & $\mathbf{U 3 3}$ & $\mathbf{U 2 3}$ & $\mathbf{U 1 3}$ & U12 \\
\hline $\mathrm{Ba} 1$ & $0.00390(10)$ & $0.00431(10)$ & $0.00586(10)$ & $0.00226(7)$ & $0.00098(7)$ & $0.00145(7)$ \\
\hline $\mathrm{P} 002$ & $0.0044(3)$ & $0.0048(3)$ & $0.0078(3)$ & $0.0030(3)$ & $0.0016(3)$ & $0.0020(2)$ \\
\hline $\mathrm{P} 003$ & $0.0057(3)$ & $0.0093(3)$ & $0.0049(3)$ & $0.0021(2)$ & $0.0014(2)$ & $0.0021(2)$ \\
\hline O004 & $0.0089(9)$ & $0.0146(10)$ & $0.0139(10)$ & $0.0104(8)$ & $0.0065(8)$ & $0.0079(8)$ \\
\hline O005 & $0.0089(9)$ & $0.0096(9)$ & $0.0066(8)$ & $0.0017(7)$ & $-0.0002(7)$ & $-0.0007(7)$ \\
\hline O006 & $0.0074(9)$ & $0.0063(9)$ & $0.0071(8)$ & $0.0015(7)$ & $0.0023(7)$ & $0.0024(7)$ \\
\hline O007 & $0.0088(9)$ & $0.0067(9)$ & $0.0065(8)$ & $0.0026(7)$ & $-0.0009(7)$ & $-0.0002(8)$ \\
\hline O008 & $0.0069(9)$ & $0.0061(9)$ & $0.0144(10)$ & $-0.0004(8)$ & $0.0000(8)$ & $0.0029(7)$ \\
\hline O009 & $0.0075(8)$ & $0.0078(9)$ & $0.0084(9)$ & $0.0051(7)$ & $0.0017(7)$ & $0.0036(7)$ \\
\hline O00A & $0.0123(10)$ & $0.0112(10)$ & $0.0130(10)$ & $0.0072(8)$ & $0.0056(8)$ & $0.0078(8)$ \\
\hline
\end{tabular}

Table 4. Main interatomic distances $(\AA)$ and angles $\left(^{\circ}\right)$ obtained for $\mathrm{Ba}\left(\mathrm{H}_{2} \mathrm{PO}_{4}\right)_{2}$.

\begin{tabular}{|c|c|c|c|c|c|}
\hline $\mathrm{O} 005-\mathrm{P} 003$ & $1.527(2)$ & $\mathrm{O} 005-\mathrm{P} 003-\mathrm{O} 007$ & $104.37(12)$ & O005-O006 & $2.536(4)$ \\
\hline $\mathrm{O} 006-\mathrm{P} 003$ & $1.512(2)$ & $\mathrm{O} 006-\mathrm{P} 003-\mathrm{O} 005$ & $113.08(13)$ & $\mathrm{O} 005-\mathrm{O} 007$ & $2.449(3)$ \\
\hline O007-P003 & $1.573(2)$ & $\mathrm{O} 006-\mathrm{P} 003-\mathrm{O} 007$ & $110.66(13)$ & O005-O00A & $2.536(4)$ \\
\hline \multirow[t]{3}{*}{$\mathrm{O} 00 \mathrm{~A}-\mathrm{P} 003$} & $1.526(2)$ & $\begin{array}{l}\mathrm{O} 006-\mathrm{P} 003-\mathrm{O} 00 \mathrm{~A} \\
147.06(4)\end{array}$ & $108.69(13)$ & $\mathrm{O} 006-\mathrm{O} 007$ & $2.538(4)$ \\
\hline & & O00A-P003-O005 & $112.33(13)$ & O006-O00A & $2.469(4)$ \\
\hline & & $\mathrm{O} 00 \mathrm{~A}-\mathrm{P} 003-\mathrm{O} 007$ & $107.52(13)$ & O007-O00A & $2.499(4)$ \\
\hline $\mathrm{O} 004-\mathrm{P} 002$ & $1.571(2)$ & $\mathrm{O} 004-\mathrm{P} 002-\mathrm{O} 008$ & $108.40(13)$ & $\mathrm{O} 004-\mathrm{O} 008$ & $2.599(3)$ \\
\hline O008-P002 & $1.585(2)$ & O009-P002-O004 & $103.04(12)$ & O004-O009 & $2.399(4)$ \\
\hline $\mathrm{O} 009-\mathrm{P} 002$ & $1.494(2)$ & $\mathrm{O} 009-\mathrm{P} 002-\mathrm{O} 00 \mathrm{~B}$ & $120.20(13)$ & $\mathrm{O} 004-\mathrm{O} 00 \mathrm{~B}$ & $2.535(4)$ \\
\hline \multirow{3}{*}{$\mathrm{O} 00 \mathrm{~B}-\mathrm{P} 002$} & $1.496(2)$ & $\mathrm{O} 00 \mathrm{~B}-\mathrm{P} 002-\mathrm{O} 004$ & $111.50(13)$ & O008-0009 & $2.526(3)$ \\
\hline & & $\mathrm{O} 00 \mathrm{~B}-\mathrm{P} 002-\mathrm{O} 008$ & $103.19(12)$ & $\mathrm{O} 008-\mathrm{O} 00 \mathrm{~B}$ & $2.415(3)$ \\
\hline & & $\mathrm{O} 009-\mathrm{P} 002-\mathrm{O} 008$ & $110.22(13)$ & $\mathrm{O} 009-\mathrm{O} 00 \mathrm{~B}$ & $2.592(4)$ \\
\hline $\mathrm{O} 004-\mathrm{Ba}$ & $2.874(2)$ & & & & \\
\hline $\mathrm{O} 005-\mathrm{Ba}$ & $2.756(2)$ & & & & \\
\hline $\mathrm{O} 006-\mathrm{Ba}$ & $2.926(2)$ & & & & \\
\hline O007-Ba & $2.832(2)$ & \multicolumn{4}{|c|}{ Shortest distances, oxygen-oxygen, between water tetrahedra } \\
\hline $\mathrm{O} 008-\mathrm{Ba}$ & $2.913(2)$ & & & & \\
\hline $\mathrm{O} 009-\mathrm{Ba}$ & $2.663(2)$ & O006-O008 & $2.671(4)$ & $\mathrm{O} 005-\mathrm{O} 005$ & $2.481(6)$ \\
\hline $\mathrm{O} 009-\mathrm{Ba}$ & $2.758(2)$ & O004-O00A & $2.572(5)$ & $\mathrm{O} 00 \mathrm{~A}-\mathrm{O} 00 \mathrm{~A}$ & $2.447(6)$ \\
\hline $\mathrm{O} 00 \mathrm{~B}-\mathrm{Ba}$ & $2.664(2)$ & & & & \\
\hline $\mathrm{O} 00 \mathrm{~B}-\mathrm{Ba}$ & $2.738(2)$ & & & & \\
\hline
\end{tabular}

The crystal structure of barium dihydrogenomonophosphate, $\mathrm{Ba}\left(\mathrm{H}_{2} \mathrm{PO}_{4}\right)_{2}$ consists of one barium $\mathrm{Ba}^{+2}$ cation and two phosphates $\left[\mathrm{H}_{2} \mathrm{PO}_{4}\right]^{-}$anions (Figure 1). The various polyhedral views along [llll $\left.\begin{array}{lll}1 & 0 & 0\end{array}\right],\left[\begin{array}{lll}0 & 1 & 0\end{array}\right]$, and [ $\left[\begin{array}{lll}0 & 0 & 1\end{array}\right]$ directions of $\mathrm{Ba}\left(\mathrm{H}_{2} \mathrm{PO}_{4}\right)_{2}$ crystal are represented in figures 2, 3, and4, respectively. The barium dihydrogenomonophosphate $\mathrm{Ba}\left(\mathrm{H}_{2} \mathrm{PO}_{4}\right)_{2}$ structure is a monophosphate whose two independent tetrahedral $\mathrm{PO}_{4}$ have mean $\mathrm{P}-\mathrm{O}$ distances of 1.54. 
They derive around the barium atom, a neighborhood of nine oxygen atoms (Figure 1). This triclinic variety is not structurally related to the orthorhombic variety. On the other hand, there are great structural analogies with $\mathrm{Ca}\left(\mathrm{H}_{2} \mathrm{AsO}_{4}\right)_{2}$ [10]. We can expect a distribution of hydrogen atoms similar to that established in $\mathrm{Ca}\left(\mathrm{H}_{2} \mathrm{AsO}_{4}\right)_{2}$.

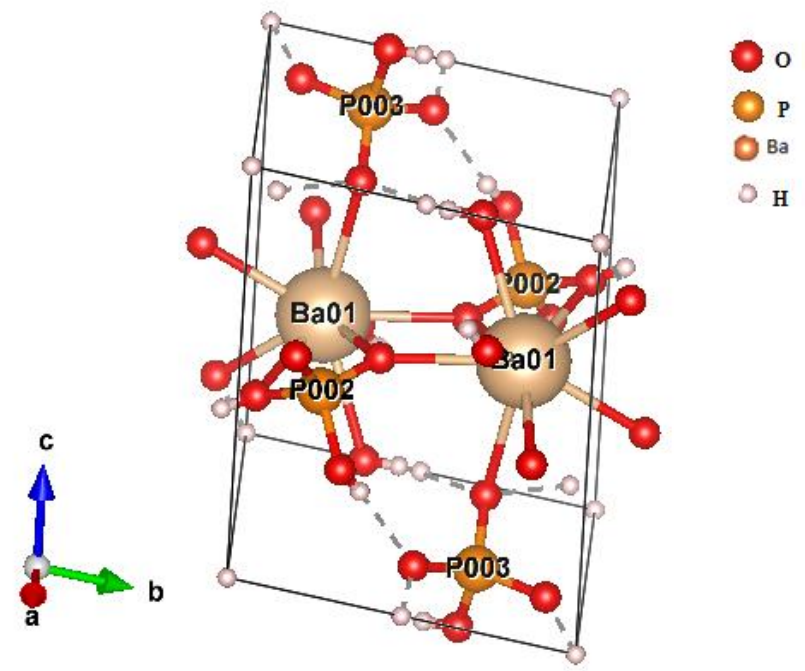

Figure 1.Tridimensional view of $\mathrm{Ba}\left(\mathrm{H}_{2} \mathrm{PO}_{4}\right)_{2}$ structure.

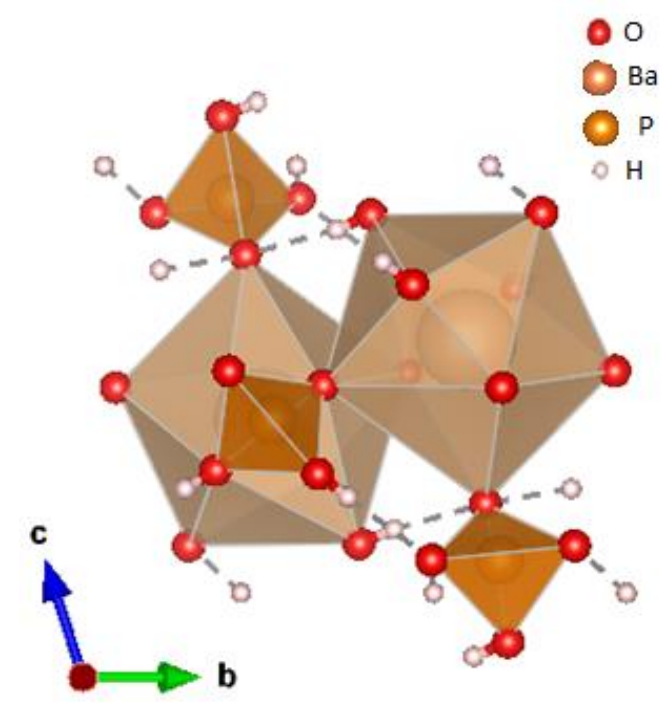

Figure 2. Polyhedral view down $\left[\begin{array}{lll}1 & 0 & 0\end{array}\right]$ direction of $\mathrm{Ba}\left(\mathrm{H}_{2} \mathrm{PO}_{4}\right)_{2}$.

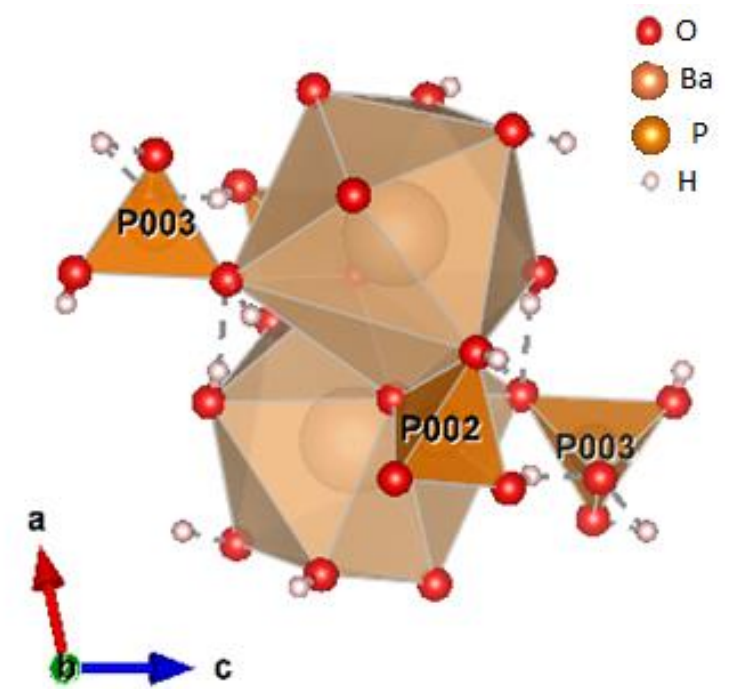

Figure 3. Polyhedral view down $\left[\begin{array}{lll}0 & 1 & 0\end{array}\right]$ direction of $\mathrm{Ba}\left(\mathrm{H}_{2} \mathrm{PO}_{4}\right)_{2}$. 
This probably involves hydrogen atoms on centers of symmetry in $1 / 2,1 / 2,1 / 2$ et $1 / 2,1 / 2,0$. By comparing the study carried out on $\mathrm{Ca}\left(\mathrm{H}_{2} \mathrm{AsO}_{4}\right)_{2}$, one can predict the important role played by the hydrogen bond in the cohesion of the tetrahedra between them in this compound.

The $\mathrm{P}(003) \mathrm{O} 4$ groups are attached to the top and bottom of the $\mathrm{P}(002) \mathrm{O} 4$ sheet by the $\mathrm{O}(008)-\mathrm{H}(008) \ldots . \mathrm{O}(006)$ and $\mathrm{O}(004)-\mathrm{H}(004) \ldots . . \mathrm{O}(00 \mathrm{~A})$ hydrogen bonds. The phosphate sheets are held together by $\mathrm{Ba}^{2+}$, which makes six of its nine coordination bonds with $\mathrm{P}(002) \mathrm{O} 4$ $\mathrm{O}$ atoms. It was observed that the shortest distances, oxygen-oxygen, between two tetrahedral, are $\mathrm{O}(5)-\mathrm{O}(5)$ and $\mathrm{O}(\mathrm{A})-\mathrm{O}(\mathrm{A}), 2.481(6)$, and 2.447(6), respectively (Table 4).

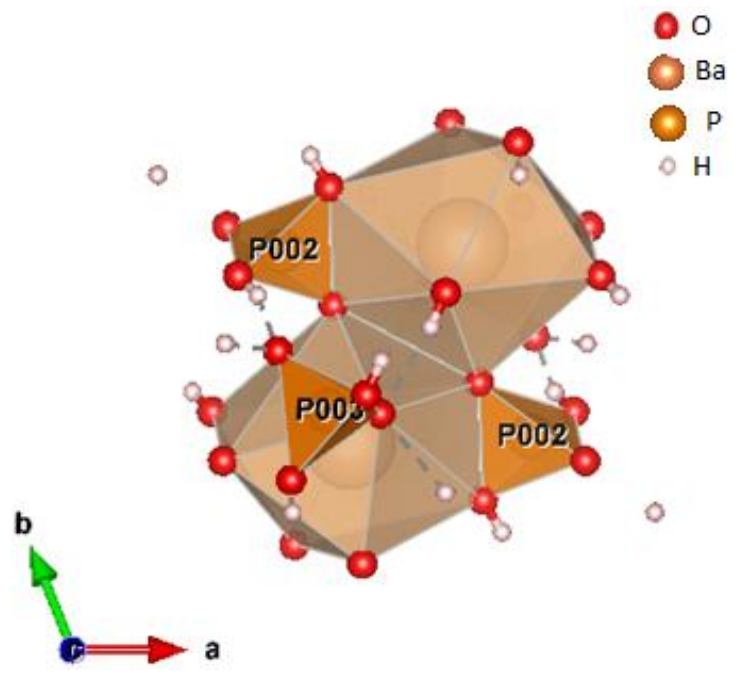

Figure 4. Polyhedral view down $\left[\begin{array}{lll}0 & 0 & 1\end{array}\right]$ of the structure of $\mathrm{Ba}\left(\mathrm{H}_{2} \mathrm{PO}_{4}\right)_{2}$.

\subsection{Computational calculations results.}

\subsubsection{X-ray and DFT comparative study.}

The crystallographic data of our sample $\mathrm{Ba}\left(\mathrm{H}_{2} \mathrm{PO}_{4}\right)_{2}$ allows us to validate the $\mathrm{B} 3 \mathrm{LYP}$ / LanL2DZ method for the structural crystallization of the compound's molecular geometry.
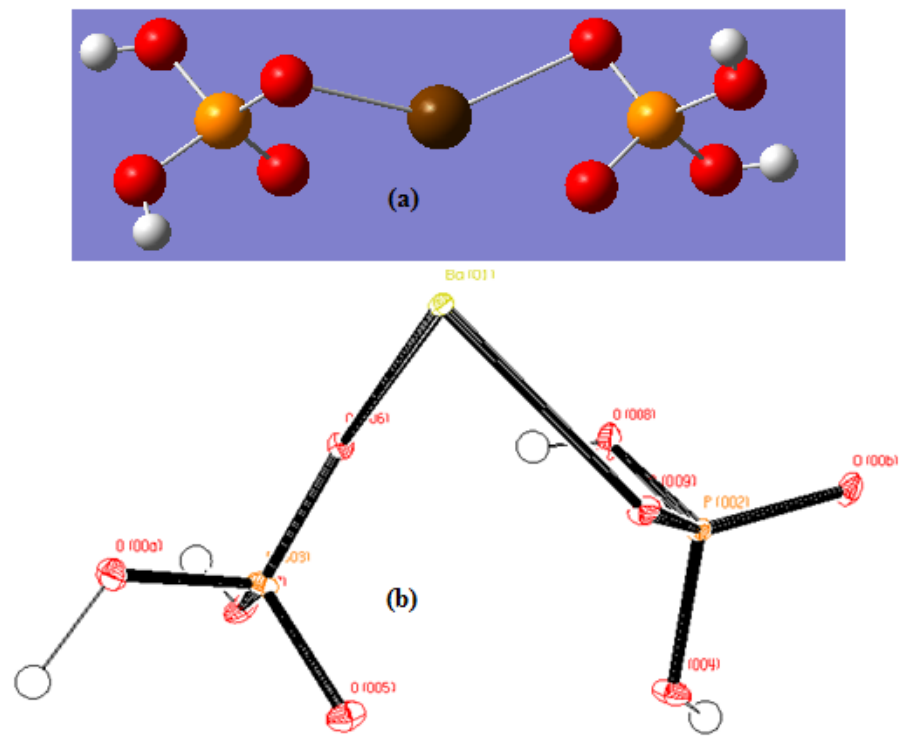

Figure 5. (a) Optimized molecular structure of $\mathrm{Ba}\left(\mathrm{H}_{2} \mathrm{PO}_{4}\right)_{2}$ using DFT B3LYP/LanL2DZ calculation (b) Molecular structure of $\mathrm{Ba}\left(\mathrm{H}_{2} \mathrm{PO}_{4}\right)_{2}$ as an ORTEP plot; displacement ellipsoids are drawn at the 50\% probability level and $\mathrm{H}$ atoms are depicted as balls with an arbitrary radius. 
Figure $5 \mathrm{a}$ and $5 \mathrm{~b}$ show us the asymmetric unit of $\mathrm{Ba}\left(\mathrm{H}_{2} \mathrm{PO}_{4}\right)_{2}$ by the ORTEP presentation and the DFT optimized geometry of $\mathrm{Ba}\left(\mathrm{H}_{2} \mathrm{PO}_{4}\right)_{2}$, respectively. The structure optimization zero-point energy of the title compound in B3LYP/LanL2DZ is -642.5367 Hartree(-17484.3242 eV).

The optimized bond length, bond angles and dihedral angles of the title compound with the experimental values and the relative error values, expressed by the difference between the DFT values and some experimental data, are shown in Table 5.

Some experimental values were found to be slightly smaller than the optimized DFT bond lengths and bond angles, so the experimental results belong to molecules in the solid state, while the theoretical calculations belong to molecules isolated in the gaseous phase.

A comparison of the calculated geometrical parameters of the isolated ions and $\mathrm{Ba}\left(\mathrm{H}_{2} \mathrm{PO}_{4}\right)_{2}$ containing the $\mathrm{O}-\mathrm{H}-----\mathrm{O}$ hydrogen bond provides information about the changes that occur upon the non-covalent bonding network and the crystal packing effect.

Table 5. Selected geometric parameters as determined by X-ray crystallography for $\mathrm{Ba}\left(\mathrm{H}_{2} \mathrm{PO}_{4}\right)_{2}$ compared to that obtained by the theoretical calculation using DFT B3LYP/LanL2DZ, with relative error values.

\begin{tabular}{|c|c|c|c|}
\hline $\mathrm{Ba}\left(\mathrm{H}_{2} \mathrm{PO}_{4}\right)$ & X-ray & DFT & Relative error \% \\
\hline Bond lengths $(\AA)$ & & & \\
\hline O006-P003 & 1.512 & 1.622 & -7 \\
\hline O005-P003 & 1.527 & 1.621 & -6 \\
\hline O007-P003 & 1.573 & 1.709 & -9 \\
\hline O00A-P003 & 1.526 & 1.692 & -11 \\
\hline O00B-P002 & 1.496 & 1.620 & -8 \\
\hline O008-P002 & 1.585 & 1.709 & -8 \\
\hline O004-P002 & 1.571 & 1.692 & -8 \\
\hline O009-P002 & 1.494 & 1.622 & -9 \\
\hline O006-Ba01 & 2.926 & 2.734 & 7 \\
\hline O009-Ba01 & 2.758 & 2.739 & 1 \\
\hline O007-H007 & 0.720 & 0.976 & -36 \\
\hline OOOA-H0OA & 1.224 & 0.979 & 20 \\
\hline O008-H008 & 0.74 & 0.9764 & -32 \\
\hline O004-H004 & 0.74 & 0.9789 & -32 \\
\hline Bond angles $\left({ }^{\circ}\right)$ & & & \\
\hline O005-P3-O006 & 113.08 & 106.868 & 5 \\
\hline O007-P3-O006 & 110.66 & 114.452 & -3 \\
\hline O005-P3-O00A & 112.33 & 112.415 & 0 \\
\hline O005-P3-O007 & 104.37 & 114.762 & -10 \\
\hline O006-P3-O00A & 108.69 & 112.567 & -4 \\
\hline O00A-P3-O007 & 107.52 & 95.708 & 11 \\
\hline O009-P2-O004 & 103.04 & 112.926 & -10 \\
\hline O009-P2-O00B & 120.20 & 106.882 & 11 \\
\hline O009-P2-O008 & 110.22 & 114.076 & -3 \\
\hline O004-P2-O00B & 111.50 & 111.962 & 0 \\
\hline O004-P2-O008 & 108.40 & 95.708 & 12 \\
\hline O00B-P2-O008 & 103.19 & 115.164 & -12 \\
\hline P2-O004-H004 & 115.00 & 119.629 & -4 \\
\hline P2-O008-H008 & 115.00 & 116.286 & -1 \\
\hline $\mathrm{P} 3-\mathrm{O} 007-\mathrm{H} 007$ & 113.00 & 119.692 & -6 \\
\hline P3-O0OA-H00A & 121.10 & 116.237 & 4 \\
\hline $\mathrm{P} 3-\mathrm{O} 006-\mathrm{Ba} 01$ & 126.62 & 97.899 & 23 \\
\hline $\mathrm{P} 2-\mathrm{O} 009-\mathrm{Ba} 01$ & 127.34 & 97.657 & 23 \\
\hline
\end{tabular}

Consequently, the geometric characteristics that we have obtained from the isolated molecules could be used as references to follow the changes which occur during the interactions of the $\mathrm{O}-\mathrm{H}-----\mathrm{O}$ hydrogen bonds in $\mathrm{Ba}\left(\mathrm{H}_{2} \mathrm{PO}_{4}\right)_{2}$. As Table 5 shows, the calculated bond lengths are slightly shorter than those of the isolated molecules.

The relative error is found to be important for some bond lengths [O00A-H00A, 20\%], [O004-H004, 32\%], [O008-H008,32\%], [O007-H007, 36\%], which are those involved in hydrogen bonding. The relative error is found to be important for some bond lengths [O00A- 
H00A, 20\%], [O004-H004, 32\%], [O008-H008,32\%], [O007-H007, 36\%], which are those involved in hydrogen bonding's O007-H007•••006 and O008-H008••O006.

Concerning the angles, an important error between experimental and theoretical data is observed for $\mathrm{P} 2-\mathrm{O} 009-\mathrm{Ba}(01)(23 \%)$ and $\mathrm{P} 2-\mathrm{O} 006-\mathrm{Ba}(01)(23 \%)$, since the $\mathrm{Sr} 1$ ion is observed between $\mathrm{O} 009$ and $\mathrm{O} 006$ as a bridging atom, that links the $\mathrm{P}(2) \mathrm{O} 4$ and $\mathrm{P}(3) \mathrm{O} 4$ groups. Generally, the B3LYP/LanL2DZ calculations could be considered reliable. It simulates the crystal structure and the bond length order in the title compound. The X-ray measurementt's structural information is in good agreement with those obtained from DFT calculations.

\subsubsection{Frontier molecular orbitals analysis.}

The HOMO-LUMO energy gap of $\mathrm{Ba}\left(\mathrm{H}_{2} \mathrm{PO}_{4}\right)_{2}$ was calculated at the $\mathrm{B} 3 \mathrm{LYP} / 6-31 \mathrm{G}(\mathrm{d})$ level. Table.6 shows the highest occupied molecular orbital (HOMO) and lowest occupied molecular orbital (LUMO). To visualize the molecular orbitals and to examine the charge, we performed the HOMO-LUMO analysis. Therefore to understand how molecules interact with other species, the two parameters mentioned are imperative (Figure 6). On the one hand, the outermost orbital containing electron, which tends to release electrons, is the highest occupied molecular orbital HOMO. On the other hand, the free space to accept electrons is the lowest unoccupied molecular orbital LUMO. The charge transfer interactions within the molecule can be explained by the HOMO-LUMO energy gap $[11,12]$.
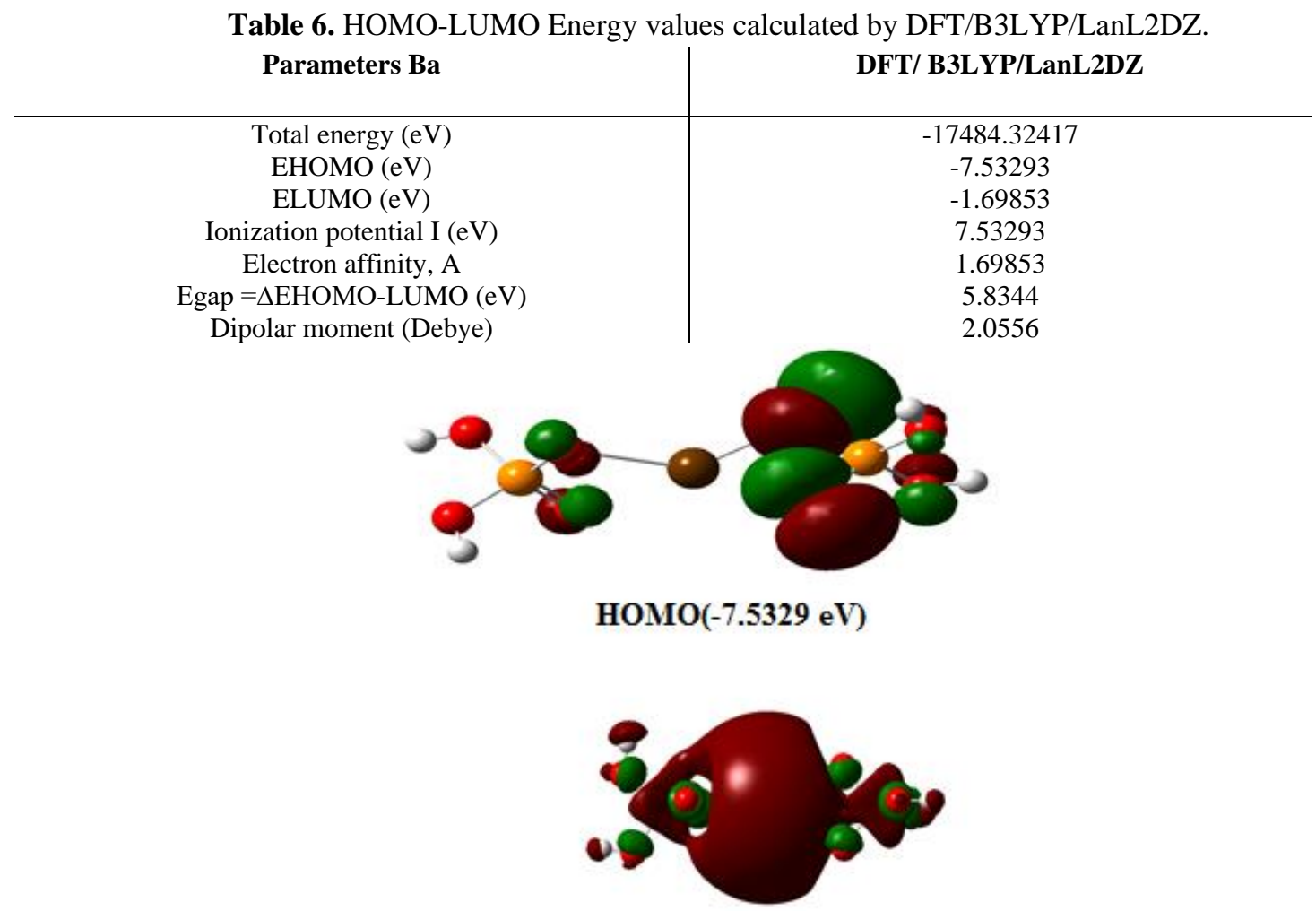

\section{LUMO(-1.6985 eV)}

Figure 6. HOMO, LUMO orbitals and their corresponding energies calculated at the DFT/B3LYP/LanL2DZ for $\mathrm{Ba}\left(\mathrm{H}_{2} \mathrm{PO}_{4}\right)_{2}$.

The positive phase is represented in red and the negative phase is represented in green. The frontier molecular orbital energies, Еномо and ELumo, are $-7.533 \mathrm{eV}$ and $-1.698 \mathrm{eV}$, respectively. Our system can be of low reactivity and of good stability because the DFT difference $(\mathrm{B} 3 \mathrm{LYP} / \mathrm{LanL} 2 \mathrm{DZ})$ calculated $\left[\mathrm{E}_{\mathrm{gap}}=\mathrm{E}_{\mathrm{LUMO}}-\mathrm{E}_{\mathrm{HOMO}}=5.834 \mathrm{eV}\right]$ is considered to 
be a relatively large bandgap [13]. We find that the energy gap is large, the molecule is not highly polarizable and has a low chemical reactivity. The ionization energy of a molecule is equal to the orbital's energy from which the electron is ejected [14]. So, the ionization energy (IE) may be defined through the DFT method as the negative of the HOMO energy [IE = Еномо $=7.5329 \mathrm{eV}]$.

\subsection{Vibrational analysis.}

\subsection{1. $\left[\mathrm{H}_{2} \mathrm{PO}_{4}\right]^{-}$vibrational mode.}

The free $\left[\mathrm{PO}_{4}\right]_{3}^{-}$tetrahedron is known to have tetrahedral symmetry Td symmetry. Therefore, it has four normal modes of vibration, with A1(v1), E(v2) and F2(v3 and v4) symmetries, with average wavenumbers of 938, 420, 1017 and $567 \mathrm{~cm}^{-1}$, respectively. All those symmetries were Raman active, except for $v 3$ and $v 4$, which were IR active [15-17]. The spectroscopic characteristics of the $\left[\mathrm{HPO}_{4}\right]^{2-}$ ion $\left(\mathrm{C}_{3 \mathrm{v}}\right.$ symmetry when is free) could be inferred from the free $\left[\mathrm{PO}_{4}\right]^{3-}$ tetrahedron. The two stretching modes, $v 1$ and $v 3$, led to a quasisymmetrical $v \mathrm{~s}\left(\mathrm{PO}_{2}\right)$ stretching mode at $976 \mathrm{~cm}^{-1}$, another $v \mathrm{~s}(\mathrm{P}-\mathrm{OH})$ stretching mode around $884 \mathrm{~cm}^{-1}$, and a quasi-degenerated vas $\left(\mathrm{PO}_{2}\right)$ state at about $1087 \mathrm{~cm}^{-1}$ (Figure6).

The fixation of two hydrogens on two oxygens ( $\mathrm{P}-\mathrm{OH}$ bonds) of the $\left[\mathrm{PO}_{4}\right]^{3-}$ group reduces the ideal symmetry $\mathrm{Td}$ to $\mathrm{C}_{2 \mathrm{v}}$, which is considered as an ideal point group symmetry of the $\left[\mathrm{H}_{2} \mathrm{PO}_{4}\right]^{-}$group.

Based on structural data ( $\mathrm{P}-1$ space group) of $\mathrm{Ba}\left(\mathrm{H}_{2} \mathrm{PO}_{4}\right)_{2}$, there are observed at the site symmetry $\mathrm{C} 1$ and are considered isolated groups. Therefore, we can enumerate the group's vibrational modes $\left[\mathrm{H}_{2} \mathrm{PO}_{4}\right]$ by applying the site group method. But, first, the determination of the vibrational modes in $\mathrm{C}_{2 \mathrm{v}}$ symmetry of the point group of $\left[\mathrm{H}_{2} \mathrm{PO}_{4}\right]^{-}$gives 15 internal vibrations active in IR and Raman, except for the A2 modes, which are only active in Raman.

$$
\Gamma \operatorname{vib}\left(\mathrm{H}_{2} \mathrm{PO}_{4}^{-}\right) .=6 \mathrm{~A} 1(\mathrm{IR}, \mathrm{Ra})+4 \mathrm{~B} 1(\mathrm{IR}, \mathrm{Ra})+2 \mathrm{~A} 2(\mathrm{Ra})+3 \mathrm{~B} 2(\mathrm{IR}, \mathrm{Ra})
$$

In fact, the correlations between the molecular group $\mathrm{Td}$ of $\left[\mathrm{PO}_{4}\right]^{3-}$ and the molecular group $\mathrm{C}_{2 \mathrm{v}}$ show the following effects (Table7): the vibrations $v 1(\mathrm{~A} 1)$ and $v 2(\mathrm{E})$ active in Raman in Td symmetry become in $\mathrm{C}_{2 \mathrm{v}}$ group $\mathrm{A} 1$ active in IR and Raman, and A1, A2; this latter mode is only Raman active in $\mathrm{C}_{2 v}$. The vibrations v3(T1) and $v 4(\mathrm{~T} 2)$ active in IR and Raman in Td remain active in IR and Raman, with splitting into three components (A1, B1, B2). Theoretically, the appearance of certain modes under a single band and the lifting of the degeneracy for others can be explained by the analysis made in group $\mathrm{C}_{2 \mathrm{v}}$.

Considering the intra-ionic coupling for the $\mathrm{PO}_{4}$ stretching vibrations due to two longer $\mathrm{P}-\mathrm{OH}$ and two shorter $\mathrm{P}-\mathrm{O}$ bonds, the four stretching modes $3 \mathrm{vas}(\mathrm{P}-\mathrm{O})(\mathrm{A} 1+\mathrm{B} 1+\mathrm{B} 2)$ and vs(P-O) (A1) mentioned in Table7 may be regarded as vs $(\mathrm{POH})$, vas $(\mathrm{POH}), v s\left(\mathrm{PO}_{2}\right)$ and $\operatorname{vas}\left(\mathrm{PO}_{2}\right)[17]$.

In addition, six vibrations involving $\mathrm{OH}$ motions are characteristic for $\mathrm{H}_{2} \mathrm{PO}_{4}$ : stretching $\mathrm{O}-\mathrm{H}[v(\mathrm{OH})]$, in-plane bending $\mathrm{POH}[\delta(\mathrm{P}-\mathrm{OH})]$ and out-of-plane bending $\mathrm{POH}$ $[\gamma(\mathrm{P}-\mathrm{OH})]$ for each $\mathrm{OH}$ bond may be added to the nine internal $\mathrm{PO}_{4}$ vibrations, which gives in total 15 fundamentals for $\left[\mathrm{H}_{2} \mathrm{PO}_{4}\right]^{-}[18]$. The vibration distribution of $\left[\mathrm{H}_{2} \mathrm{PO}_{4}\right]^{-}$in the factor group $\mathrm{Ci}$ is obtained by performing correlations between the $\mathrm{C}_{2 \mathrm{v}}$ molecular group of $\left[\mathrm{H}_{2} \mathrm{PO}_{4}\right]^{-}$ and the $\mathrm{C} 1$ site group which it occupies in the crystal and correlations between the site group and the group factor $\mathrm{Ci}$ corresponding to the space group P-1. The results obtained are given 
in Table 8, we deduce the 30 vibrational modes representation $\Gamma$ vib of the $\left[\mathrm{H}_{2} \mathrm{PO}_{4}\right]^{-}$ion in the crystal.

$$
\Gamma \operatorname{vib}\left(\mathrm{H}_{2} \mathrm{PO}_{4}\right)=15 \mathrm{Ag}(\mathrm{Ra})+15 \mathrm{Au}(\mathrm{IR})
$$

Table 8 shows that all vibrational modes of $\left[\mathrm{H}_{2} \mathrm{PO}_{4}\right]^{-}$in group molecular $\mathrm{C}_{2 \mathrm{v}}$ are theoretically Raman and infrared active in the group factor. Due to the presence of the center of symmetry in the crystal (P-1), the Raman active modes of symmetry Ag are not active in infrared where the activity corresponds to Au symmetry and vice versa [19].

Table 7. Internal vibration correlation diagram of the $\mathrm{PO}_{4}$ group in $\left[\mathrm{H}_{2} \mathrm{PO}_{4}\right]^{-}$.

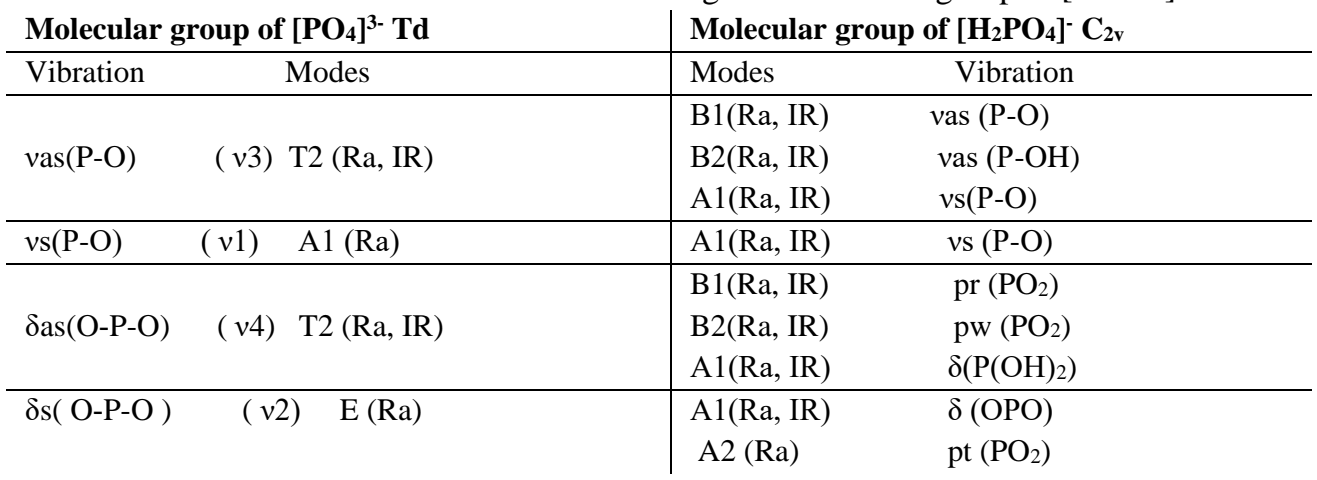

Table 8. Correlation diagram of $\left[\mathrm{H}_{2} \mathrm{PO}_{4}\right]^{-}$group in the crystal $\mathrm{Ba}\left(\mathrm{H}_{2} \mathrm{PO}_{4}\right)_{2}$.

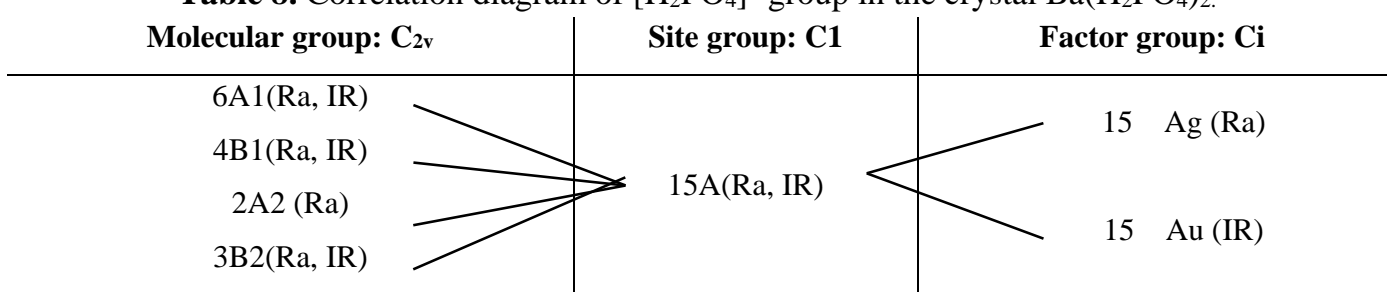

\subsubsection{Infrared and Raman spectra.}

The infrared and Raman spectra of $\mathrm{Ba}\left(\mathrm{H}_{2} \mathrm{PO}_{4}\right)_{2}$ recorded at room temperature are shown in Figures7 and 8, respectively, which exhibits one distinct region between 400-1300 $\mathrm{cm}^{-1}$, corresponding to the internal vibrational modes of phosphate $\left[\mathrm{H}_{2} \mathrm{PO}_{4}\right]^{-}$ion. Based on the theoretical analysis, all the bands observed in the infrared spectrum are considered with the symmetry $\mathrm{Au}$ of the factor group $\mathrm{Ci}$, whereas those observed in the Raman spectrum are taken as Ag symmetry (Table 9). Comparing the spectral data obtained for the dihydrogen phosphate in the Refs [18-20]. We can interpret the bands due to $\left[\mathrm{H}_{2} \mathrm{PO}_{4}\right]^{-}$ion. The vibrations corresponding to in-plane bending $\delta(\mathrm{P}-\mathrm{OH})$ and to out-of-plane bending $\gamma(\mathrm{P}-\mathrm{OH})$ modes of phosphate $\left[\mathrm{H}_{2} \mathrm{PO}_{4}\right]^{-}$ion are characteristic for acidic phosphates since they are absent in normal phosphates. It is to note that the in-plane and out-of-plane bending vibrations occur in the region $1350-1200 \mathrm{~cm}^{-1}$ and $950-750 \mathrm{~cm}^{-1}$, respectively [21, 22].

For the title compound, the strong band at $1218 \mathrm{~cm}^{-1}$ can be assigned to the active Infrared in-plane modes $\delta(\mathrm{P}-\mathrm{OH})$. The components stretching $v 3(v a s \mathrm{P}-\mathrm{OH})$ and $v 1(v s \mathrm{P}-\mathrm{OH})$, vibrations of the $\left[\mathrm{H}_{2} \mathrm{PO}_{4}\right]^{-}$may be the features observed as strong and medium absorptions bands at $976 \mathrm{~cm}^{-1}$ and $884 \mathrm{~cm}$-1in the IR spectrum(Figure 7). The shoulder band at $733 \mathrm{~cm}^{-1}$ may be assigned to the out-of-plane bending $\gamma(\mathrm{P}-\mathrm{OH})$. This is observed in the Raman spectrum as weak bands at $741 \mathrm{~cm}^{-1}$ (Figure 8 ).

The asymmetric bending $v 4(\delta$ as $\mathrm{O}-\mathrm{P}-\mathrm{O})$ of the phosphate $\left[\mathrm{H}_{2} \mathrm{PO}_{4}\right]-$ anion appeared as medium and strong Infrared bands at $547 \mathrm{~cm}^{-1}$ and $507 \mathrm{~cm}^{-1}$, respectively. The Infrared medium 
band observed at $432 \mathrm{~cm}^{-1}$ is assigned to the symmetric stretching modesv2( $\left.\delta \mathrm{s} \mathrm{O}-\mathrm{P}-\mathrm{O}\right)$ [2329].

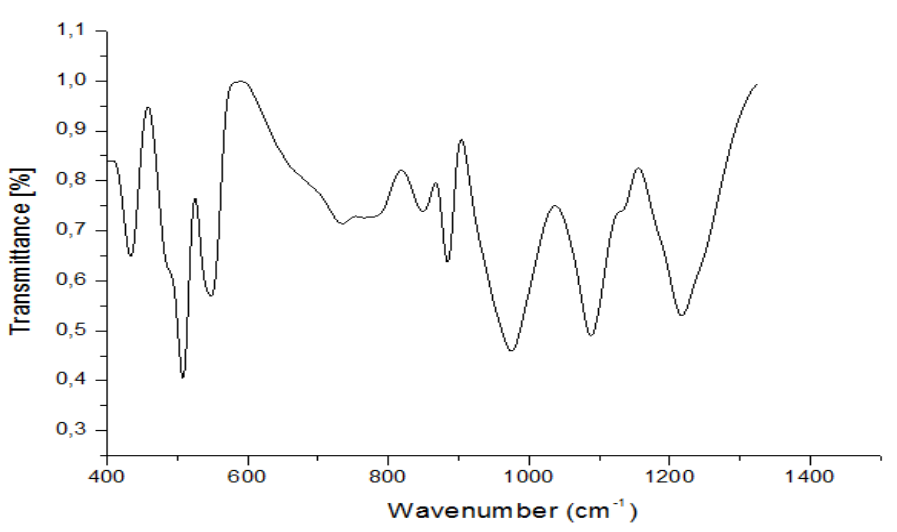

Figure 7. IR spectrum of $\mathrm{Ba}\left(\mathrm{H}_{2} \mathrm{PO}_{4}\right)_{2}$.

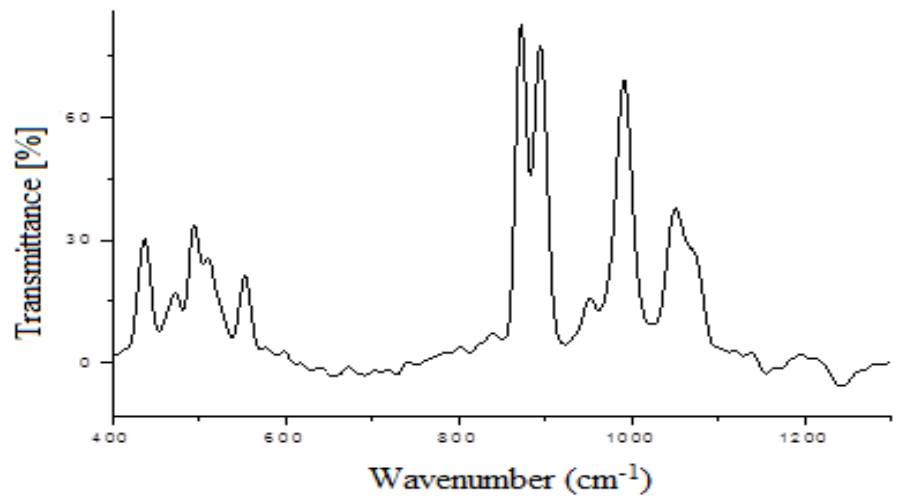

Figure 8. Raman spectrum of $\mathrm{Ba}\left(\mathrm{H}_{2} \mathrm{PO}_{4}\right)_{2}$.

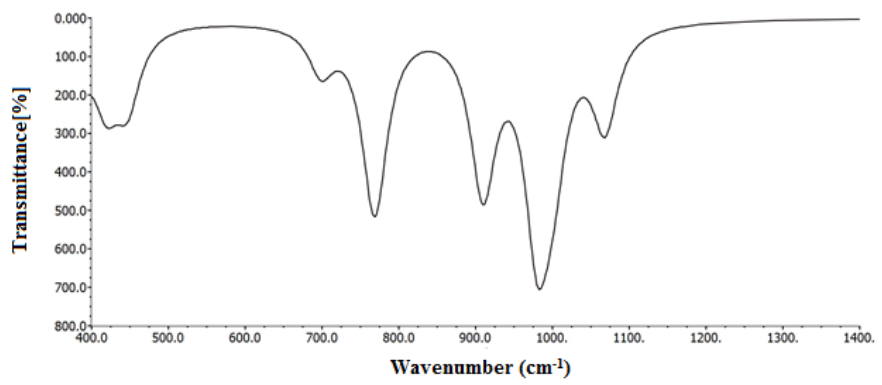

Figure 9. The infrared spectrum of $\mathrm{Ba}\left(\mathrm{H}_{2} \mathrm{PO}_{4}\right)_{2}$ calculated by the DFT B3LYP/LanL2DZ method.

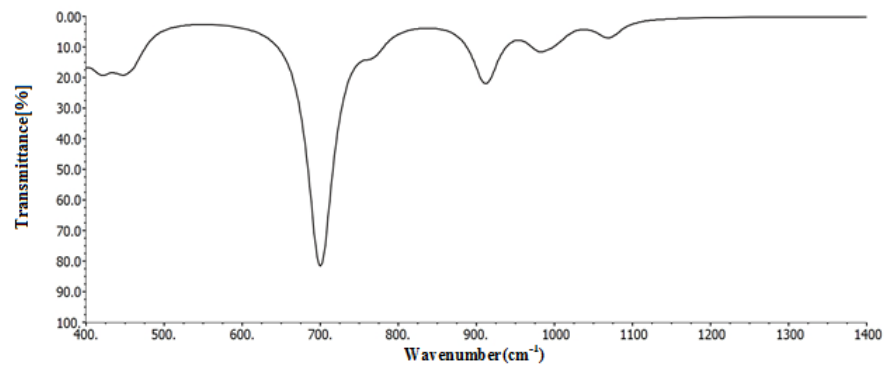

Figure 10. The Raman activity spectrum of $\mathrm{Ba}\left(\mathrm{H}_{2} \mathrm{PO}_{4}\right)_{2}$ calculated by the DFT B3LYP/LanL2DZ method.

\section{Conclusions}

Barium dihydrogenomonophosphate, $\mathrm{Ba}\left(\mathrm{H}_{2} \mathrm{PO}_{4}\right)_{2}$ has been prepared by the direct method. $\mathrm{Ba}\left(\mathrm{H}_{2} \mathrm{PO}_{4}\right)_{2}$ is isostructural with barium dihydrogenomonophosphate, $\mathrm{Sr}\left(\mathrm{H}_{2} \mathrm{PO}_{4}\right)_{2}$, and crystallizes in the triclinic system with space group $\mathrm{P}-1(\mathrm{Z}=2)$. 
Table 9. Experimental and calculated values of the vibration wavenumbers $\left(\mathrm{cm}^{-1}\right)$ for $\mathrm{Ba}\left(\mathrm{H}_{2} \mathrm{PO}_{4}\right)_{2}$.

\begin{tabular}{|c|c|c|c|c|}
\hline \multicolumn{4}{|c|}{ Bands v $\left(\mathrm{cm}^{-1}\right)$} & \multirow[t]{2}{*}{ Assignments } \\
\hline $\begin{array}{c}\text { IR }(\mathrm{Au}) \\
\text { Experimental } \\
\text { Figure } 7\end{array}$ & $\begin{array}{c}\text { IR (Au) } \\
\text { DFT } \\
\text { Figure 9 }\end{array}$ & $\begin{array}{c}\text { Raman (Ag) } \\
\text { Experimental } \\
\text { Figure } 8\end{array}$ & $\begin{array}{c}\text { Raman (Ag) } \\
\text { DFT } \\
\text { Figure 10 }\end{array}$ & \\
\hline 1218 & - & - & - & $\delta(\mathrm{P}-\mathrm{OH})$ \\
\hline 1127 & - & - & - & $v_{3}\left(v_{\text {as }} \mathrm{PO}_{2}\right)$ of $\left[\mathrm{H}_{2} \mathrm{PO}_{4}\right]^{-}$ \\
\hline 1087 & 1066 & 1052 & 1069 & $v_{1}\left(v_{\mathrm{s}} \mathrm{PO}_{2}\right)$ of $\left[\mathrm{H}_{2} \mathrm{PO}_{4}\right]^{-}$ \\
\hline 976 & $\begin{array}{l}909 \\
983\end{array}$ & $\begin{array}{l}990 \\
951\end{array}$ & $\begin{array}{l}979 \\
912\end{array}$ & $v_{3}\left(v_{\text {as }} \mathrm{P}-\mathrm{OH}\right)$ of $\left[\mathrm{H}_{2} \mathrm{PO}_{4}\right]^{-}$ \\
\hline $\begin{array}{l}884 \\
850\end{array}$ & - & $\begin{array}{l}895 \\
870\end{array}$ & - & $\begin{array}{c}v_{1}\left(v_{\mathrm{s}} \mathrm{P}-\mathrm{OH}\right) \text { of }\left[\mathrm{H}_{2} \mathrm{PO}_{4}\right]^{-/} / \gamma(\mathrm{P}- \\
\mathrm{OH})\end{array}$ \\
\hline 733 & $\begin{array}{l}767 \\
698\end{array}$ & 741 & $\begin{array}{l}768 \\
700\end{array}$ & $\gamma(\mathrm{P}-\mathrm{OH})$ \\
\hline $\begin{array}{l}547 \\
507\end{array}$ & $\begin{array}{l}- \\
-\end{array}$ & $\begin{array}{l}555 \\
511\end{array}$ & $\begin{array}{l}- \\
-\end{array}$ & $v_{4}\left(\delta_{\mathrm{as}} \mathrm{O}-\mathrm{P}-\mathrm{O}\right)$ of $\left[\mathrm{H}_{2} \mathrm{PO}_{4}\right]^{-}$ \\
\hline 432 & $\begin{array}{l}441 \\
420\end{array}$ & 437 & $\begin{array}{l}449 \\
420\end{array}$ & $v_{2}\left(\delta_{\mathrm{s}} \mathrm{O}-\mathrm{P}-\mathrm{O}\right)$ of $\left[\mathrm{H}_{2} \mathrm{PO}_{4}\right]^{-}$ \\
\hline
\end{tabular}

The title compound is studied by single-crystal X-ray diffraction analysis, infrared and Raman vibrational. The molecular geometry, harmonic vibrational frequencies, infrared intensities and Raman scattering activities were calculated by using the density functional theory (DFT/B3LYP) methods with the LanL2DZ basis set. The bands observed in the infrared and Raman spectra of $\mathrm{Ba}\left(\mathrm{H}_{2} \mathrm{PO}_{4}\right)_{2}$ are assigned as a function of the results obtained in the literature and the theoretical group analyses carried out in the factor group Ci. The threedimensional structure can be considered as consisting of independent $\left[\mathrm{PO}_{4}\right]$ tetrahedra. Two vertices of each tetrahedron $\left[\mathrm{PO}_{4}\right]^{3-}$ are connected to two $\mathrm{H}$ atoms to form phosphate $\left[\mathrm{H}_{2} \mathrm{PO}_{4}\right]^{-}$ anions arranged to delimit large deformed cavities occupied by barium-cations. The hydrogen atoms were positioned in idealized positions and included in the final cycles of refinement. The HOMO-LUMO properties have been studied and discussed. The theoretical results have been found to agree with the experimental results.

\section{Funding}

This research received no external funding.

\section{Acknowledgments}

The authors are indebted to Dr. Jakub Wojciechowski and Rigaku Oxford diffraction for the $\mathrm{X}$-ray measurements to solve the crystal structure.

\section{Conflicts of Interest}

The authors declare no conflict of interest.

\section{References}

1. Königstein, D.; Jansen; M. Crystal structure of strontium dihydrogenphosphate, $\operatorname{Sr}\left(\mathrm{H}_{2} \mathrm{PO}_{4}\right)_{2}$. Z. Kristallogr. 1998, 213,736-736, https://doi.org/10.1524/ncrs.1998.213.14.736.

2. Gilbert, J.D.; Lenhert, P. G.; and Wilson; L.K.Orthorhombic barium dihydrogenphosphate. Acta Cryst. 1977, B33, 3533-3535. https://doi.org/10.1107/S0567740877011376.

3. Okabe, K.; Kobayashi, E. A Study of Inorganic Ion Exchangers. XI. The Hydrothermal Reactions of $\mathrm{ZrOCl}_{2}$ and $\mathrm{M}\left(\mathrm{H}_{2} \mathrm{PO}_{4}\right)_{2} \quad(\mathrm{M}=\mathrm{Mg}, \quad \mathrm{Ca}, \quad \mathrm{Sr}, \quad \mathrm{Ba})$. Bull. Chem. Jpn 1987, 60, 2825-2831, https://doi.org/10.1246/bcsj.60.2825. 
4. Gholivand, M. B.; Sobhani, S.; Khirdoosh, F. 2-Aminocyclopentene-1-Dithiocarboxylic Acid-Naphthalene Adsorbent for the Preconcentration and Determination of a Trace Copper in Real Samples by Spectrophotometric Method. J. Chin. Chem. Soc. 2002, 49, 355-359. https://doi.org/10.1002/jccs.200200055.

5. Lin, Q.; Zheng, F.; Lu, T.-T.; Liu, J.; Li, H.; Wei, T.-B.; Yao,H.; Zhang, Y.-M. A novel imidazophenazinebased metallogel act as reversible $\mathrm{H}_{2} \mathrm{PO}_{4}{ }^{-}$sensor and rewritable fluorescent display material. Sensors and Actuators B: Chemical 2017, 251, 250-255, https://doi.org/10.1016/j.snb.2017.05.053.

6. Saravana Kumar, S.; Kumar R.S.; Ashok Kumar, S. K. An “Off-On-Off” type fluorescent chemosensor for the relay detection of $\mathrm{Zn}^{2+}$ and $\mathrm{H}_{2} \mathrm{PO}_{4}^{-}$in aqueous environment. Inorganica Chimica Acta 2019, 502, 119348, https://doi.org/10.1016/j.ica.2019.119348.

7. Ponomareva, V. G.; Bagryantseva, I. N. The influence of $\mathrm{Cs}_{2} \mathrm{HPO}_{4} \cdot \mathrm{H}_{2} \mathrm{O}$ impurity on the proton conductivity and thermal properties of $\mathrm{CsH}_{2} \mathrm{PO}_{4}$. Solid State Ionics 2019, 329, 90-94. https://doi.org/10.1016/j.ssi.2018.11.021.

8. Bagryantseva, I. N.; Ponomareva, V. G. Proton conductivity and thermal properties of $\mathrm{Ba}\left(\mathrm{H}_{2} \mathrm{PO}_{4}\right)_{2}$. Inorganic Materials 2018, 54 , 4, 366-373. https://doi.org/10.1134/S0020168518040027.

9. Le magueres, P.; Reinheimer, E.W.; Meyer, M.; Jones, A.; Kucharczyk, D.The Rigaku Oxford Diffraction XtaLAB Synergy-S, a versatile microfocus sealed tube diffractometer for weakly diffracting samples. $\begin{array}{lllll}\text { Foundations } \quad \text { of } & \text { Crystallography } & \mathbf{2 0 1 8}, & 74, & \text { https://sci- }\end{array}$ hub.se/https://journals.iucr.org/a/issues/2018/a1/00/a57017/a57017.pdf.

10. Ferraris, G.; Jones, D.W.; Yerkess, J.A. Neutron diffraction study of the crystal structure of calcium bis(dihydrogen arsenate), $\mathrm{Ca}\left(\mathrm{H}_{2} \mathrm{AsO}_{4}\right)_{2}$. Acta Cryst. 1972, B28, 2430-2437, https://doi.org/10.1107/S0567740872006247.

11. Nakamoto, K. Infrared and Raman Spectra of Inorganic and Coordination Compounds.Handbook of Vibrational Spectroscopy, 2006, https://doi.org/10.1002/0470027320.s4104.

12. Jalbout, A. F.; Hameed, A. J.; Trzaskowski, B. Study of the structural and electronic properties of 1-(4, 5 and 6-selenenyl derivatives-3-formyl-phenyl) pyrrolidinofullerenes. Journal of organometallic chemistry 2007, 692, 1039-1047, https://doi.org/10.1016/j.jorganchem.2006.10.068.

13. Ouasri, A.; El-Adel, L.; Zouihri, H.; Rhandour, A.; Jalbout, A.F. TGA, Hirshfeld, Raman spectroscopy and computational studies of diethylammonium hexachloroplumbate $\left[\left(\mathrm{C}_{2} \mathrm{H}_{5}\right)_{2} \mathrm{NH}_{2}\right]_{2} \mathrm{PbCl}_{6}$. Journal of Molecular Structure 2018, 1157, 621-630, https://doi.org/10.1016/j.molstruc.2017.12.093.

14. Stefov,V.; Koleva,V.; Najdoski,M.; Cahil, A.; Abdija, Z. Infrared and Raman spectra of magnesium ammonium phosphate hexahydrate (struvite) and its isomorphous analogues. X. Vibrational spectra of magnesium rubidium arsenate hexahydrate and magnesium thallium arsenate hexahydrate. Maced. J. Chem. Chem. Eng. 2020, 39, 239-249, https://doi.org/10.20450/mjcce.2020.2168.

15. Sarker, D.; Hossen, M.F.; Kudrat-E-Zahan, M.; Rausan, Z.; Asraf, A. Cu(II) complex of 1-naphthaldehyde semicarbazone: synthesis, characterization, thermal analysis and antibacterial activity. AJARR 2020, 10, https://doi.org/10.9734/ajarr/2020/v10i130231.

16. Antony, C.J.; Aatiq, A.; Panicker, C.Y.; Bushiri, M.J.; Varghese, H.T.; Manojkumar, T. K. FT-IR and FTRaman study of Nasicon type phosphates, ASnFe $\left(\mathrm{PO}_{4}\right)_{3}\left[\mathrm{a}=\mathrm{Na}_{2}, \mathrm{Ca}, \mathrm{Cd}\right]$. Spectrochimica Acta Part A 2011, 78, 415-419, https://doi.org/10.1016/j.saa.2010.11.003.

17. Kugel,G.E.; Brehat, F.; Wyncke, B.; Fontana; M.D. Marnier, G.; Carabatos-Nedelec, C.; Mangin, J. The vibrational spectrum of a KTiOPO4 single crystal studied by Raman and infrared reflectivity spectroscopy. Phys. C: Solid State Phys. 1988, 21, 5565-5583, https://sci-hub.se/10.1088/0022-3719/21/32/011.

18. ElMakhloufy, S.; Majdi, E.M.; Ouasri, A.; Chtita, S.; Saadi, M.; Ammari, L.E.; Cherqaoui, A.; Belaaouad, S. Synthesis, crystal structure, IR, Raman-spectroscopy and DFT computation of monostrontium phosphate monohydrate, $\mathrm{Sr}\left(\mathrm{H}_{2} \mathrm{PO}_{4}\right)_{2} \bullet \mathrm{H}_{2} \mathrm{O}$. Journal of Coordination Chemistry 2020, 1-19. https://doi.org/10.1080/00958972.2020.1815014.

19. Koleva,V.; Stefov,V.; Cahil, A.; Najdoski, M.; Šoptrajanov, B.; Engelen, B.; Lutz, H. D. Infrared and Raman studies of manganese dihydrogen phosphate dihydrate, $\mathrm{Mn}\left(\mathrm{H}_{2} \mathrm{PO}_{4}\right)_{2} \cdot 2 \mathrm{H}_{2} \mathrm{O}$.I: Region of the vibrations of the phosphate ions and external modes of the water molecules. Journal of Molecular Structure 2009, 917, 117 124, https://doi.org/10.1016/j.molstruc.2008.07.002.

20. Koleva,V.; Stefov, V. Phosphate ion vibrations in dihydrogen phosphate salts of the type $\mathrm{M}\left(\mathrm{H}_{2} \mathrm{PO}_{4}\right)_{2} \cdot 2 \mathrm{H}_{2} \mathrm{O}$ $(\mathrm{M}=\mathrm{Mg}, \mathrm{Mn}, \mathrm{Co}, \mathrm{Ni}, \mathrm{Zn}, \mathrm{Cd})$ : Spectra-structure correlations. Vibrational Spectroscopy 2013, 64, 89-100, https://doi.org/10.1016/j.vibspec.2012.11.004. 
21. Zerraf, Z.; Tridane, M.; Belaaouad, S; Crystal structure, vibrational and spectroscopic study of single crystal $\left(\mathrm{C}_{6} \mathrm{H}_{15} \mathrm{~N}_{4} \mathrm{O}_{2}\right) \mathrm{H}_{2} \mathrm{PO}_{4} \cdot \mathrm{H}_{2} \mathrm{O}$. Moroccan Journal of Chemistry 2020, 8, 428-438, https://doi.org/10.48317/IMIST.PRSM/morjchem-v8i2.16988.

22. Muthuselvi, C.; ShagayaPrincy, A.; Pandiarajan, S.S. Growth and Characterization of 4-carboxyanilinium DihydrogenPhosphate Semi-organic Complex Crystal. AJAPS 2017, 10, 159-169, https://doi.org./10.3923/ajaps.2017.159.169.

23. Oubouaza, R.; Marouani, H.; Zerraf, S.; Belhabra, M.; Ouasri, A.; Tridane, M.; Belaaouad, S. Chemical preparations, crystal data for monophosphates and condensed phosphates associated to strontium and IR studies of their anions. IJETER 2020, 8, 6587-6598, https://doi.org/10.30534/ijeter/2020/196892020.

24. Zerraf, S.; Belhabra, M.;Tridane, M.; and Belaaouad, S. Chemical Preparation, Thermal Behavior and IR Studies of the New Chromium Diphosphate Hydrate and Crystal Structure of its Corresponding Anhydrous Biointerface Research in Applied Chemistry 2021, 11, 13412-13420, https://doi.org/10.33263/BRIAC115.1341213420.

25. Marouani, H.; Oubouaza, R.; Zerraf, S.; Belhabra, M.; Ouasri, A.; Tridane, M.; Belaaouad, S. Chemical preparations, crystal data for monophosphates and condensed Phosphates associated to manganese and IR studies of their anions. IJETER 2020, 8, 4784 - 4798, https://doi.org./10.30534/ijeter/2020/116882020.

26. Zerraf,S.; Tridane, M.; Belaaouad, S. Data of infrared vibration spectroscopy of cyclotriphosphates. Data in Brief 2019, 25, 104075, https://doi.org/10.1016/j.dib.2019.104075.

27. Belhabra, M.; Zerraf,S.; Kheireddine, A.; Altomare, A.; Tridane, M.; Ouasri, A.; Radid, M.; Belaaouad, S. Structural and vibrational study of diphenylhyfrazine dihydrogenophosphate single crystal $\left(\mathrm{C}_{6} \mathrm{H}_{9} \mathrm{~N}_{2}\right)_{2} \mathrm{H}_{2} \mathrm{P}_{2} \mathrm{O}_{7}$ (DPHDP). Chemical Data Collections https://doi.org/10.1016/j.cdc.2018.01.002.

28. Atibi, A.; El Kababi, K.; Belhabra, M.; Zerraf, S.; Tridane, M. and Belaaouad,S. Chemical preparation, crystal structure and vibrational study of a new dihydrogenotriphosphate trihydrate of 4-aminobenzoic acid fertilizer type NP. Journal of Coordination Chemistry 2018, 1-11, https://doi.org/10.1080/00958972.2018.1528579.

29. Zerraf, S.; Belhabra, M.; Kheireddine, A.; Lamsatfi, R.;Tridane, M.; Moutaabbid, H.; Baptiste, B.; Moutaabbid, B.; Belaaouad, S. Reinvestigation of the crystal structure of barium and cesium cyclotriphosphate dihydrate $\mathrm{BaCsP}_{3} \mathrm{O}_{9} \cdot 2 \mathrm{H}_{2} \mathrm{O}$ and vibrational study. Phosphorus, Sulfur Relat. Elem. 2017, 192, 1286-1293, https://doi.org/10.1080/10426507.2017.1333507. 